\title{
Thermonuclease and enterotoxin production and biotyping of staphylococci isolated from moroccan dairy products
}

\author{
A. HAMAMA \\ Département d'Hygiène et Industrie des Denrées Alimentaires \\ d'Origine Animale (H.I.D.A.O.A.). \\ Institut Agronomique et Vétérinaire Hassan II, B.P. 6202 Rabat-Instituts, Rabat, Morocco
}

\section{Summary}

Examination of eighty four strains of staphylococci isolated from cow's raw milk and moroccan traditionally made dairy products for their thermonuclease (TNase) production showed that all $S$. aureus strains were positive for this test. The TNase amounts produced were variable with the non-toxigenic $S$. aureus strains being slightly more TNase producers than the toxigenic strains. Coagulase-negative staphylococci were found to be negative for the TNase test except for S. hyicus strains. Enterotoxigenicity was detected in $37.5 \%$ of $S$. aureus strains. The proportions of these strains producing SEA, SEC and SED were 33.3, 44.4 and $11.1 \%$ respectively. The origin of the strains was estimated by their biotype. All the $S$. aureus strains isolated from raw milk had an animal origin while those from buttermilk and butter had both animal ( 35.3 and $33.3 \%$ respectively) and human (47.1 and $66.6 \%$ respectively) origins. The human strains were found to produce mainly SEA while the bovine were producing either SEC or SED.

Key words : Milk - Dairy products - Staphylococci - S. aureus - Thermonuclease Enterotoxins - Biotyping.

\section{Résumé}

Production de thermonuclease et d'entérotoxines et biotypage des staphylocoques isolés des produits laitiers marocains

L'examen de la production en thermonuclease (TNase) de quatre-vingt-quatre souches de staphylocoques isolées à partir du lait cru de vache et des produits laitiers traidtionnels marocains a montré que l'ensemble des souches de $S$. aureus était positif pour ce test. Les quantités en TNase produites étaient variables avec une production légèrement plus élevée pour les souches non-toxinogènes que pour les toxinogènes. A l'exception des souches de $S$. hyicus, toutes les autres souches de staphylocoques à coagulase négatif étaient TNase négatif. L'entérotoxigénicité a été détectée chez 37,5\% 
des souches de $S$. aureus. Des proportions de $33,3,44,4$ et $11,1 \%$ de ses souches produisaient respectivement les entérotoxines staphylococciques A, C et D. L'origine des souches a été estimée par biotypage. Toutes les souches de $S$. aureus isolées du lait cru ayaient une origine animale alors que celles isolées du babeurre et du beurre avaient à la fois une origine animale (respectivement 35,3 et $33,3 \%$ ) et une origine humaine (respectivement 47,1 et $66,6 \%$ ). Les souches d'origine humaine produisaient essentiellement l'entérotoxine du type A alors que les souches d'origine animale produisaient soit l'entérotoxine du type C ou D.

Mots clés : Lait - Produits laitiers - Staphylocoques - S. aureus - Thermonuclease Entérotoxines - Biotypage.

\section{Introduction}

Besides the coagulase test, the production of thermo-stable nuclease (TNase) has been proposed as a reliable test for the correct identification of Staphylococcus aureus (LACHICA et al., 1969 ; LACHICA et al., 1971 a,b ; BARRY et al., 1973 ; Rayman et al., 1975 ; Sperber, 1976 ; Menzies, 1977). However, TNase production is not an exclusive property of $S$. aureus since $S$. hyicus (Devriese et al., 1978), Streptococcus feacalis and some species of the genus Bacillus (BissonnetTe et al., 1980 ; Batish et al., 1984) have also been found capable of TNase production.

All enterotoxigenic $S$. aureus strains have been reported to be TNase producers (Simkovikova et al., 1971 ; Lachica et al., 1972; RAyman et al., 1975 ; SPERBER et al., 1975), however, only a certain proportion of $S$. aureus strains is considered to be enterotoxigenic. The level of this proportion as well as the type of enterotoxin produced is depending on the source of isolation (CASMan et al., 1967 ; Olson et al., 1970; Simkovikova et al., 1971 ; Terayama et al., 1972 ; Untermann, 1973 ; Olsvik et al., 1981 ; Reali, 1982).

Except for a few reports showing enterotoxin production by coagulasenegative staphylococci (DANIELSON et al., 1977; OLSviK et al., 1982), the production of the staphylococcal type of enterotoxin by other coccal strains than $S$. aureus is not yet established.

Biotyping of $S$. aureus has been used in an attempt to clarify the origin (human or animal) of this organism and the probable source of contamination of foods by $S$. aureus (HaJek et al., 1971 ; Devriese, 1984).

The purpose of this investigation was to evaluate for the first time the TNase and enterotoxin production by $S$. aureus and by coagulase-negative staphylococci isolated from raw milk and dairy products produced in Morocco. The determination of the probable origin of the $S$. aureus isolates has also been attempted. 


\section{Material and methods}

\section{A. Staphylococcal strains}

Eighty four cultures of staphylococci obtained from cow's raw milk and from four traditionally made moroccan dairy products (buttermilk, butter, fresh cheese and yogurt) were used in this study. Among them, there were twenty four strains of $S$. aureus isolated from raw milk, buttermilk and butter. The remaining sixty cultures were coagulase-negative staphylococci obtained from all the five products.

\section{B. Thermonuclease production}

Staphylococci cultures grown for $24 \mathrm{~h}$ on BHI broth were tested for TNase production. The BHI cultures were heated at $100{ }^{\circ} \mathrm{C}$ for $15 \mathrm{~min}$ and allowed to cool. Few drops of these cultures were used to fill a 3-mm well cut into a toluidine-blue DNA agar plate. The TB-DNA medium was prepared as described by CoRDs et al. (1973). After $4 \mathrm{~h}$ - incubation at $50{ }^{\circ} \mathrm{C}$ as recommended by IвRAнIм (1981), the TB-DNA plates were observed for a pink halo around each well which is measured. To determine the TNase concentration, a standard curve (fig. 1) was prepared using purified micrococcal nuclease (Sigma Co. St. Louis, MO) dissolved in distilled water containing $0.1 \%$ bovine serum albumin.

\section{Enterotoxin production and detection}

The staphylococci cultures used in this study were tested for their ability to produce detectable amounts of enterotoxins using the semi-soft agar medium of CASMAN et al. (1963) for staphylococcal growth and enterotoxin production. The detection of enterotoxins was performed by using the microslide double diffusion method of CASMAN et al. (1969). Reference enterotoxins (A, B, C, D, E) and their antisera were kindly offered by Dr. S.R. TAtini (Food Science and Nutrition Dept., University of Minnesota, U.S.A.).

\section{Biotyping of S. aureus strains}

The biotype of the twenty four $S$. aureus strains was determined according to the procedure of Devriese (1984). This procedure is based on tests for $\beta$ haemolysin, staphylokinase, coaguiation of bovine plasma and the crystal-violet reaction.

\section{Results and discussion}

Species-distribution of the staphylococcal cultures used in this study is given in table 1 . $S$. aureus strains came from three products raw milk, buttermilk and butter. $S$. hyicus strains were isolated from raw milk only while 


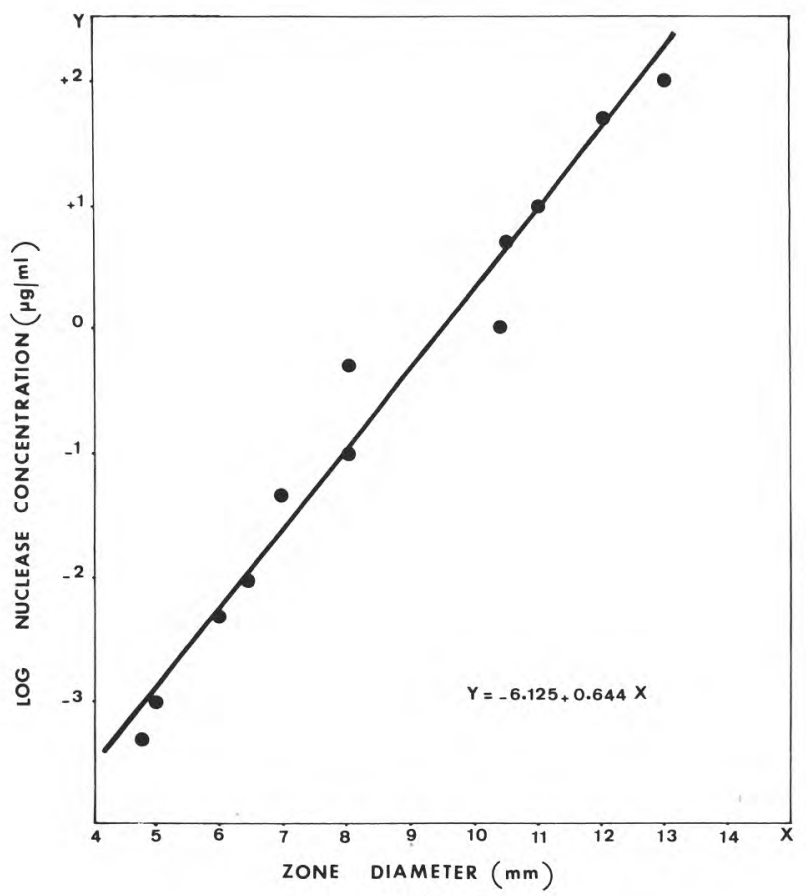

Fig. 1

Relationship between purified nuclease concentration and the pink zone diameter in Toluidine Blue-DNA agar.

Relation entre la concentration en nuclease purifié et le diamètre de la zone rose sur gélose DNA au Bleu de Toluidine.

TABLE 1

Species-distribution of staphylococci isolated from raw milk and various maroccan dairy products

Distribution par espèce des staphylocoques isolés à partir du lait cru et de différents produits laitiers marocains

\begin{tabular}{l|c|c|c|c}
\hline \multirow{2}{*}{ Product } & \multicolumn{4}{|c}{ Number of staphylococcal isolated used in the study } \\
\cline { 2 - 5 } & S. aureus & S. hyicus & $\begin{array}{c}\text { Other } \\
\text { coagulase- } \\
\text { negative } \\
\text { staphylococci }\end{array}$ & Total \\
\hline Raw milk & 4 & 7 & 15 & 26 \\
Buttermilk & 17 & 0 & 8 & 25 \\
Butter & 3 & 0 & 12 & 15 \\
Yogurt & 0 & 0 & 7 & 7 \\
Fresh Cheese & 0 & 0 & 11 & 11 \\
\hline Total & 24 & 7 & 53 & 84 \\
\hline
\end{tabular}


the other coagulase-negative staphylococci were isolated from raw milk and the dairy products studied. Data on the production of TNase and enterotoxins by $S$. aureus strains isolated from raw milk and traditionally made Moroccan dairy products are shown in table 2 . All the twenty four strains of $S$. aureus used were found to be TNase producers. This is in conformance with the findings of the majority of the authors who considered, for this reason, TNase production as one of the constant features of $S$. aureus. The average TNase production by $S$. aureus strains used in this study was 12.92 and $14.36 \mu \mathrm{g} / \mathrm{ml}$ for toxigenic and non-toxigenic strains of $S$. aureus respectively. This result showing higher TNase production by non-toxigenic strains of $S$. aureus compared to the toxigenic ones has also been reported by NISKANEN et al. (1977) who showed TNase production of 19.4 and $25.5 \mu \mathrm{g} / \mathrm{ml}$ for toxigenic and non-toxigenic strains respectively. The incidence of enterotoxigenic strains among coagulasepositive ranged from 25 percent for strains isolated from raw milk to 41.2 percent for those isolated from buttermilk. For the overall dairy products tested, the incidence of enterotoxigenic strains of $S$. aureus was of 37.5 percent. This incidence of enterotoxigenicity observed is not unusual since the dairy products used in this study were not involved with any staphylococcal outbreaks. Simкоvikova et al.(1971) reported enterotoxigenicity in 33 percent of S. aureus strains from marketed foods while REALI (1982) found 47.2 percent of $S$. aureus strains from various samples of food to be enterotoxigenic. In a similar study, HiLl (1983) reported enterotoxigenicity in 36 percent of $S$. aureus strain isolated from various dairy products regularly produced in New-Zealand. The type of enterotoxins produced are also given in table 2.

TABLE 2

TNase and enterotoxin production by S. aureus strains isolated from raw milk, buttermilk and butter

Production de la TNase et d'entérotoxines par les souches de S. aureus isolées du lait cru, du babeurre et du beurre

\begin{tabular}{|c|c|c|c|c|c|c|}
\hline \multirow{2}{*}{ Product } & \multirow{2}{*}{$\begin{array}{l}\text { No of } \\
\text { strains } \\
\text { tested }\end{array}$} & \multirow{2}{*}{$\begin{array}{c}\text { Enterotoxin } \\
\text { producers } \\
\text { No }\end{array}$} & \multirow{2}{*}{$\begin{array}{c}\text { Enterotoxin } \\
\text { produced } \\
\text { type (No) }\end{array}$} & \multirow{2}{*}{$\begin{array}{l}\text { TNase } \\
\text { producers } \\
\text { No }\end{array}$} & \multicolumn{2}{|c|}{$\begin{array}{c}\text { Average TNase } \\
\text { produced in } \mu \mathrm{g} / \mathrm{ml}\end{array}$} \\
\hline & & & & & Toxigenic & $\begin{array}{c}\text { Non- } \\
\text { Toxigenic }\end{array}$ \\
\hline Raw milk & 4 & 1 & $\begin{array}{l}\text { C (1) } \\
\text { A (3) }\end{array}$ & 4 & 12.50 & 13.81 \\
\hline Buttermilk & 17 & 7 & $\begin{array}{l}\text { C (3) } \\
\text { D (1) }\end{array}$ & 17 & 12.98 & 15.02 \\
\hline Butter & 3 & 1 & $\mathrm{AC}(1)$ & 3 & 13.00 & 11.90 \\
\hline Total & 24 & 9 & $\begin{array}{r}\text { A (3) } \\
\text { C (4) } \\
\text { D (1) } \\
\text { AC (1) }\end{array}$ & 24 & 12.92 & 14.36 \\
\hline
\end{tabular}


Out of nine enterotoxigenic strains of $S$. aureus found in raw milk, buttermilk and butter, four strains $(44.4 \%$ ) were producing enterotoxin $\mathrm{C}$ (SEC), three produced SEA $(33.3 \%)$ and one SED $(11.1 \%)$. One strain from butter $(11.1 \%)$ was found to produce both enterotoxins $\mathrm{A}$ and $\mathrm{C}$. None of the strains were found to produce either SEB or SEE. In raw milk, $S$. aureus were found to produce only SEC while in buttermilk, strains producing either SEA or SEC were present. It is known that strains from cows or dairy products are usually producing staphylococcal enterotoxins of type $\mathrm{C}$ or $\mathrm{D}$, while those from food poisoning outbreaks are usually of type A (CASMAN et al., 1967 ; OLSVIK et al., 1981; HrL, 1983). The presence of $S$. aureus producing SEA in buttermilk and butter may be explained by their human origin as indicated by their biotype (table 4). These strains had probably contaminated these two dairy products during their traditional processing which involves several handling steps.

The examination of the sixty strains of coagulase-negative staphylococci was negative except for the seven strains of $S$. hyicus which were positive for this test. The average amount of TNase produced by $S$. hyicus strains was $14.32 \mu \mathrm{g} / \mathrm{ml}$. The production of TNase by other coccal strains than $S$. aureus or $S$. hyicus has been reported by few authors (LoTter et al., 1977; Gramoli et al., 1978), but it seems that these strains are only variant or mutant of $S$. aureus.

As already shown by other authors (LACHICA et al., 1969 ; BARRY et al, 1973 ; RAYMAN et al., 1975 ; Sperber, 1976), the data on TNase production presented in this paper showing the production of TNase by all $S$. aureus strains but not by coagulase-negative staphylococci except $S$. hyicus demonstrate the efficiency of using simultaneoulsy coagulase and TNase test for differentiating $S$. aureus from $S$. hyicus and from other coagulase-negative staphylococci.

On the other hand, all coagulase-negative staphylococci used in this study were unable to produce detectable amounts of the tested enterotoxins by the method used in this work. Although some authors (DANIELSON et al., 1977, OLsvik et al., 1982) have reported enterotoxigenicity among coagulase-negative staphylococci, it is not yet established that coagulase-negative staphylococci are capable of any enterotoxin production. The report of enterotoxigenicity among these organisms could be explained by the use in those studies of more sensitive tests (e.g. Elisa test) than the gel diffusion methods for enterotoxin detection. However, these very sensitive tests have the inconvenient of allowing for more false positive reactions than the gel diffusion methods.

The biotype of $S$. aureus strains isolated from raw milk, buttermilk and butter are given in table 3 . The four strains of $S$. aureus obtained from raw milk had all an animal origin (bovine biotype for three strains and ovine biotype for one strain). Strains of human biotype were found in buttermilk and butter and they represented 47.1 and $66.6 \%$ of the total strains isolated from these two products respectively. Three strains of $S$. aureus from buttermilk $(17.6 \%)$ had non-host specific biotype while six strains had bovine type $(35.3 \%)$. As it has been already mentioned, the presence of $S$. aureus of human biotype in buttermilk and butter is probably due to the human handling of these two products during their manufacture. The contamination of dairy 
products by human strains of $S$. aureus should be prevented since some of these strains are enterotoxigenic as shown in table 4. About 42.85 percent of the enterotoxigenic strains from buttermilk were of human biotype. Therefore, products in which human contamination allows for $S$. aureus entry are likely to be a public health hazard from staphylococcal enterotoxins.

\section{TABLE 3}

Biotyping of S. aureus strains isolated from raw milk, buttermilk and butter Biotypage des souches de $\mathrm{S}$. aureus isolées du lait cru, du babeurre et du beurre

\begin{tabular}{|c|c|c|c|c|c|}
\hline \multirow{2}{*}{ Product } & \multirow{2}{*}{$\begin{array}{c}\text { No of strains } \\
\text { tested }\end{array}$} & \multicolumn{4}{|c|}{ Biotype (No) } \\
\hline & & Human & Bovine & Ovine & $\begin{array}{c}\text { Non-host } \\
\text { specific }\end{array}$ \\
\hline Raw milk & 4 & 0 & 3 & 1 & 0 \\
\hline Buttermilk & 17 & 8 & 6 & 0 & 3 \\
\hline Butter & 3 & 2 & 1 & 0 & 0 \\
\hline Total & 24 & 10 & 10 & 1 & 3 \\
\hline
\end{tabular}

TABLE 4

Biotyping and TNase production of enterotoxigenic strains of $\mathrm{S}$. aureus isolated from raw milk, buttermilk and butter

Biotypage et production de la TNase par les souches enterotoxigéniques de S. aureus isolées du lait cru, du babeurre et du beurre

\begin{tabular}{l|l|c|c|l}
\hline Strain & Source & $\begin{array}{c}\text { TNase level } \\
\text { produced } \\
\mu \mathrm{g} / \mathrm{ml}\end{array}$ & $\begin{array}{c}\text { Enterotoxin } \\
\text { produced }\end{array}$ & \multicolumn{1}{|c}{ Biotype } \\
\hline R13 & Raw milk & 12.53 & $\mathrm{C}$ & Bovine \\
L5 & Buttermilk & 9.44 & $\mathrm{~A}$ & Human \\
L8 & Buttermilk & 8.02 & $\mathrm{~A}$ & Human \\
L12 & Buttermilk & 15.57 & $\mathrm{C}$ & Bovine \\
L13 & Buttermilk & 11.25 & D & Bovine \\
L19 & Buttermilk & 9.52 & $\mathrm{C}$ & Non-host specific \\
L21 & Buttermilk & 16.04 & $\mathrm{C}$ & Bovine \\
L25 & Buttermilk & 21.34 & A & Human \\
B3 & Butter & 13.76 & AC & Human \\
\hline
\end{tabular}

This study emphasizes the need for further investigation into the incidence of enterotoxigenic strains of $S$. aureus in other traditional moroccan dairy 
products (salty butter, aged butter and different varieties of fermented dairy products) as well as the determination of their source of contamination by $S$. aureus using both the biotyping and phage typing systems.

Reçu le 19 septembre 1986.

Accepté pour publication le 10 décembre 1986.

\section{Acknowledgments}

This research work was supported in a part by a grant form the U.S. Agency for International Development.

\section{References}

Barry A.L., LAChica R.V.F., Atchinson F.W., 1973. Identification of Staphylococcus aureus by simultaneous use of tube coagulase and thermonuclease tests. Appl. Microbiol., 25, 496-497.

Batish V.K., Chander H., Ranganathan B., 1981. Screening of milk and milk products for thermonuclease. J. Food Sci., 49, $1196-1197$ and 1199.

Bissonette N., Lachance R.A., Goulet J., Landgraf M., Park C.E., 1980. Evidence of thermonuclease production by Bacillus spp. and enterococci in naturally contaminated cheese. Can. J. Microbiol, 26, 722-725.

Casman E.P., Bennett R.W., 1963. Culture medium for the production of staphylococcal enterotoxin A. J. Bacteriol., 86, 18-23.

Casman E.P., Bennett R.W., Dorsey A., Issa J.A., 1967. Identification of a fourth staphylococcal enterotoxin, enterotoxin D. J. Bacteriol., 94, 1875-1882.

Casman E.P., Bennett R.W., Dorsey A., Stone J.E., 1969. Detection of staphylococcal enterotoxins. Health Lab. Sci., 6, 185-198.

Cords B.R., TAtinı S.R., 1973. Applicability of heat-stable deoxyribonuclease assay for assessment of staphylococcal growth and the likely presence of enterotoxin in cheese. J. Dairy Sci., 56 , 1512-1519.

Danielson M.L., Hellberg B., 1977. The biochemical activity of enterotoxin and non-enterotoxin producing staphylococci. Acta Vet. Scand., 18, 266-273.

DeVriese L.A., 1984. A simplified system for biotyping Staphylococcus aureus strains isolated from different animal species. J. Appl. Bacteriol., 56, 215-220.

Devriese L.A., Hajek V., Oeding P., Meyer S.A., Schleifer K.H., 1978. Staphylococcus hyicus (Sompolinsky 1953) comb. nov. and Staphylococcus hyicus subsp. chormogenes subsp. nov. Int. J. Syst. Bacteriol., 28, 482-490.

Gramoli J., Wilkinson B.J., 1978. Characterization and identification of coagulase-negative, heatstable deoxyribonuclease positive staphylococci. J. Gen. Microbiol., 105, 275-285.

HajeK V., Marsalek E., 1971. The differenciation of pathogenic staphylococci and a suggestion for their taxonomic classification. Zentralbl. Bakteriol. Parasitenkd. Infektionskr. Hyg. Abt 1, Orig., Reihe A, 217, 176-182.

Hill B.M., 1983. Enterotoxin-producing Staphylococcus aureus isolated from milk and dairy products. N. Z. J. Dairy Sci. Technol., 18, 59-62.

Iвraнiм G.F., 1981. A simple sensitive method for determining staphylococcal thermonuclease in cheese. J. Appl. Bacteriol., 48, 307-312.

LaChicha R.V.F., Genigeorgis C, Hoeprich P.D., 1971 a. Metachromatic agar diffusion methods for detecting staphylococcal nuclease activity. Appl. Microbiol., 21, 585-587. 
Lachicha R.V.F., Hoeprich P.D., Genigorgis C., 1971 b. Nuclease production and lysostaphin susceptibility of Staphylococcus aureus and other coagulase-positive cocci. Appl. Microbiol., $21,823-826$.

Lachicha R.V.F., Hoeprich P.D., Genigeorgis C., 1972. Metachromatic agar-diffusion microslide technique for detecting staphylococcal nuclease in foods. Appl. Microbiol., 23, 168-169.

LACHICHA R.V.F., Weiss K.F., Diebel R.H., 1969. Relationships among coagulase, enterotoxin and heat-stable deoxyribonuclease production by Staphylococcus aureus. Appl. Microbiol., 18, $126-127$.

Lotter L.P., Genigeorgis C., 1977. Isolation of coagulase-positive variants from coagulasenegative enterotoxigenic staphylococci. Zentralbl. Bakteriol. Parasitenkd. Infektionskr. Hyg. Abt. 1 Orig. Reihe A, 239, 18-30.

Menzies R.E., 1977. Comparison of coagulase, deoxyribonuclease (DNase) and heat-stable nuclease tests for identification of Staphylococcus aureus. J. Clin. Pathol., 30, 606-608.

Niskanen A., Koiranen L., 1977. Correlation of enterotoxin and thermonuclease production with some physiological and biochemical properties of staphylococcal strains from different sources. J. Food Prot., 40, 543-548.

Olson J.C. J', Casman E.P., Baer E.F., Stone J.E., 1970. Enterotoxigenicity of Staphylococcus aureus cultures isolated from acute cases of bovine mastitis. Appl. Microbiol., 20, 605-607.

Olsvik O., Berdal B.P., Fossum K., Omland T., 1981. Enterotoxin production by Staphylococcus aureus related to the origin of the strains. Acta Pathol. Microbiol. Scand. Sect. B, 89, 423426.

Olsvik O., Fossum K., Berdal B.P., 1982. Staphylococcal enterotoxin A, B and C produced by coagulase-negative strains within the family Micrococcaceae. Acta Pathol. Microbiol. Scand. Sect. $B, 90,441-444$.

Rayman M.K., Park C.E., Philpott J., Todd E.C.D., 1975. Reassessment of the coagulase and thermostable nuclease tests as means of identifying Staphylococcus aureus. Appl. Microbiol., $29,451-454$.

REALI D., 1982. Enterotoxin A and B production in strains of Staphylococcus aureus isolated from human beings and foods. J. Hyg., 88, 103-106.

Simlovikova M., Gilbert R.J., 1971. Serological detection of enterotoxin from food-poisoning strains of Staphylococcus aureus. J. Med. Microbiol., 4, 19-30.

SPERBER W.H., TATINI S.R., 1975. Interpretation of the tube coagulase test for identification of Staphylococcus areus. Appl. Microbiol., 29, 502-505.

Terayama T., Igarashi H., Lishioda H., Zen-Yoji H., 1972. Studies on staphylococcal foodpoisoning (III). Enterotoxin productivity and coagulase types of strains of Staphylococcus aureus originated from food-poisoning incidents, healthy subjects and commercial foods. $J$. Food Hyg. Soc. Jap., 13, 459-556.

Untermann F., 1973. Mastitis - staphylokokken and enterotoxine. $6^{\text {th }}$ International Symposium of W.A.V.F.H., Elsinove, Denmark. 